International Review of Research in Open and Distributed Learning Volume 16, Number 6

November - 2015

\title{
Opportunities and Threats of the MOOC Movement for Higher Education: The European Perspective
}

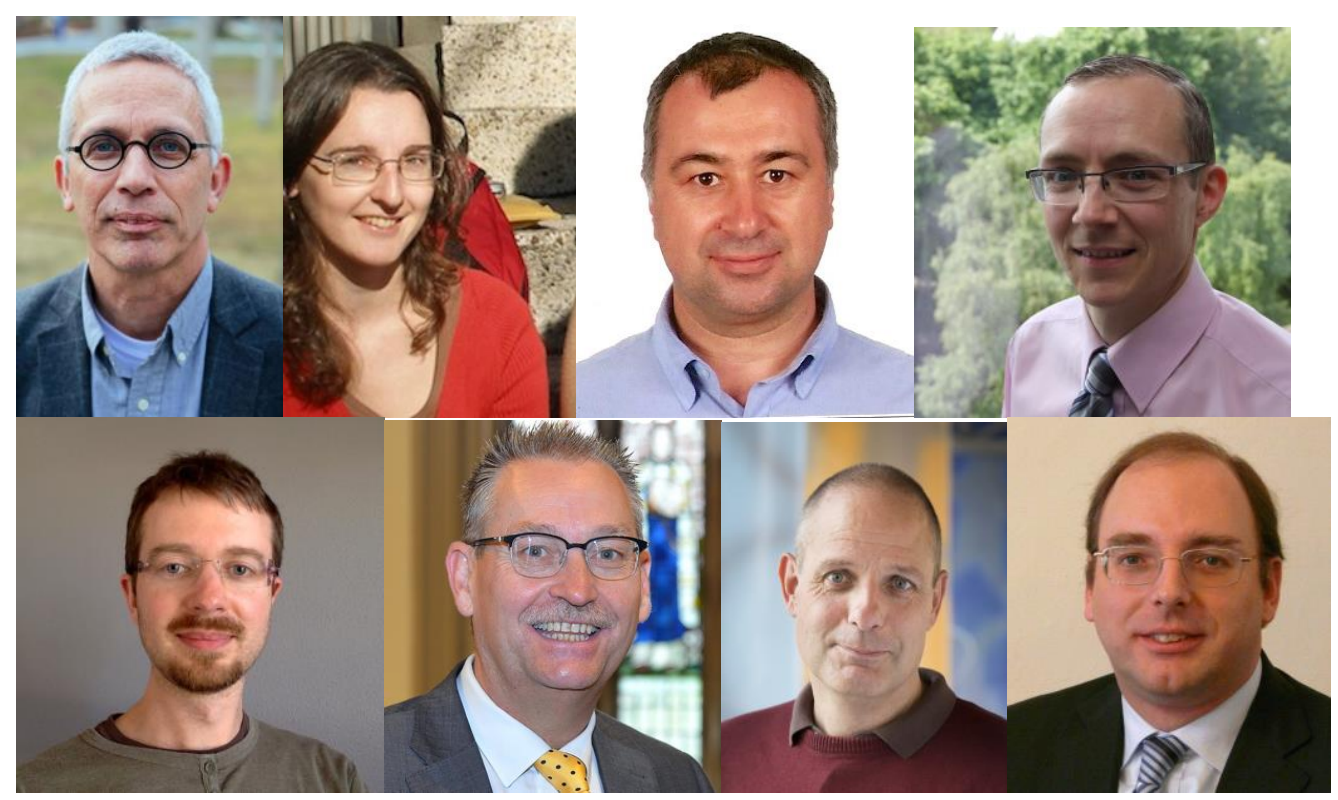

Robert Schuwer, Inés Gil-Jaurena, Cengiz Hakan Aydin, Eamon Costello, Christian Dalsgaard, Mark Brown, Darco Jansen and Antonio Teixeira

Fontys University of Applied Sciences, The Netherlands, Universidad Nacional de Educación a Distancia, Spain, Anadolu University, Turkey, Dublin City University, Ireland, Aarhus University, Denmark, Dublin City University, Ireland, EADTU, the Netherlands, Universidade Aberta, Portugal

\begin{abstract}
The Massive Open Online Course (MOOC) movement is the latest "big thing" in Open and Distance Learning (ODL). MOOCs offer both opportunities and threats that are extensively discussed in the literature, including the potential of opening up education for all at a global scale.
\end{abstract}


On the other hand, MOOCs challenge traditional pedagogy and raise important questions about the future of campus-based education. However, in discussing these opportunities and threats the majority of the literature tends to focus on the origin of the MOOC movement in the United States (US). The specific context of Europe with its diversity of languages, cultural environments, educational policies, and regulatory frameworks differs substantially from the US context. Accordingly, this article offers a European perspective on MOOCs in order to better understand major differences in threats and opportunities across countries and continents, including the use and reuse of MOOCs for regional or global use, via European or non-European platforms. In the context of the EU funded HOME project (Higher education Online: MOOCs the European way), a research initiative was undertaken to identify opportunities and threats of the MOOC movement for European higher education institutions. Three sources of data were gathered and analysed. Opportunities and threats were categorized into two levels. The macro level comprises issues related to the higher education system, European context, historical period, and institutional concerns. The micro level covers aspects related to faculty, teachers, and courses, thus to the operational level. The main opportunities discovered were: the ECTS as a robust system for formal recognition of accomplishments in MOOCs; the trend for institutional collaboration, stimulated by EU-funded programs; and the many innovative and alternative pedagogical models used in MOOCs published in Europe. The main threats mentioned were: implementation problems of the ECTS, difficulties in bridging non/informal and formal education; and too much regulation, hindering experimentation and innovation.

Keywords: MOOC, Europe, Opportunities, Threats

\section{Introduction}

The Massive Open Online Course (MOOC) movement is the latest "big thing" in Open and Distance Learning (ODL) to threaten to transform higher education in a significant way. Put simply, MOOCs are “...courses designed for large numbers of participants, that can be accessed by anyone anywhere as long as they have an internet connection, are open to everyone without entry qualifications, and offer a full/complete course experience online for free" (OpenupEd, 2015). Within this definition an important distinction needs to be made between institutionally focused xMOOCs and the connectivist origins of so-called cMOOCs. However, regardless of this distinction the disruptive impact of MOOCs remains unclear and we should not forget the long history of "hope, hype and disappointment" (Gouseti, 2010) that characterises many claims about the revolutionary potential of previous technological innovations in ODL.

At one end of the "hype continuum" there are predictions that MOOCs are a metaphorical avalanche that will totally transform higher education (Barber, Donnelly \& Rizvi, 2013). This school of thought raises serious questions about the future of formal education and traditional universities. The MOOC has become a symbol of a larger modernisation agenda for universities

This work is licensed under a Creative Commons Attribution 4.0 International License. 
and is intertwined with the concept of unbundling and related economic imperatives about the viability, scalability, and sustainability of higher education (Selwyn, 2014). At the other end of the continuum, despite the hope of opening up access to higher education through new models of online learning to millions of people in the developing world, we have been disappointed by the fact that MOOCs report high dropout rates and generally attract already well-educated learners (Macleod, Haywood, Woodgate \& Alkhatnai, 2015). As Macleod et al. (2015) observe the vast majority of learners are well-educated, often with several degrees, and in employment. Moreover, the courses are dominated by a handful of platforms supported by elite universities and very few MOOCs offer formal pathways to recognised academic qualifications.

Krause and Lowe (2014) present a useful synthesis of the claims made about the promise and perils of MOOCs. On the one hand, they show that MOOCs have the potential to challenge the closed and privileged nature of academic knowledge in traditional universities. That said, in many respects this feature of openness is a profound second order outcome of the Internet rather than a result of MOOCs per se. Nevertheless, the growth of the MOOC has potential to address the problem of meeting increasing demand for higher education, particularly in developing countries where it is almost impossible to build enough traditional institutions to cope with the number of prospective students. In this regard, Daniel (2012) believes the new openness movement is a real game changer, as it has potential to widen access to life-long learning, address key gaps in skill development, and ultimately enhance the quality of life for millions. There is even some hope in Europe that MOOCs may be able to play an important role in closing the growing inequality gap and in reducing youth unemployment. In this regard, the European Credit Transfer and Accumulation System (ECTS) can probably play a role in bridging non-formal and formal learning. ECTS (2009) describes the ECTS as:

"a tool that helps to design, describe, and deliver programmes and award higher education qualifications. The use of ECTS, in conjunction with outcomes-based qualifications frameworks, makes programmes and qualifications more transparent and facilitates the recognition of qualifications. ECTS can be applied to all types of programmes, whatever their mode of delivery (school-based, workbased), the learners' status (full-time, part-time) and to all kinds of learning (formal, non-formal and informal)" (p. 7).

One example of ECTS as a foundation for bridging non-formal and formal education, is the model used by the iMOOC experience: "A critical element of the Model is its contribution to facilitate the transition from non-formal education to formal education through certification. This is majorly played by the way certification options are embedded in the courses." (Teixeira \& Mota, 2014, p. $514)$.

On the other hand, MOOCs are seen as nothing more than a clever marketing ploy by elite universities (Krause \& Lowe, 2014). Selwyn, Bulfin and Pangrazio (2015) argue in their analysis of 
the discursive construction of MOOCs in the popular media that the frenzy around the MOOC movement conceals a number of contradictory messages. For example, despite claims of disrupting traditional higher education systems, the legitimacy of the MOOC movement as an educational innovation appears to derive primarily from its association with high status, elite universities (Selwyn et al., 2015). In addition, they point out that so-called new models of online massive pedagogy are heralded as innovative using the best of Web 2.0 technology, whilst derided by more critical and contemporary educators as merely replicating the passive instructionism of the 2oth century.

Peters' (2013) critique (as cited in Brown \& Costello, 2014) goes further by arguing that MOOCs reflect a new academic labour policy for globalised universities, an expression of Silicon Valley neo-liberal values, and a kind of entertainment media that is the oxymoron of serious and meaningful learning. In a similar vein, Barlow suggests the MOOC is just another neo-colonialist tool reproducing privilege (Barlow, 2014). Once again, Selwyn et al.'s (2015) analysis of the popular portrayal of MOOCs in the media is useful, as they help us to peel away some of the competing and co-existing discourses of persuasion. The key point is that different interest groups and stakeholders have quite different reasons for promoting MOOCs and the opening up of education agenda must be seen alongside powerful forces that view online learning as a means of increasing competition between institutions, introducing new business models with reduced public funding for universities, and the creation of a global higher education digital marketplace (Brown, 2015).

While more scholarly literature reviews of the opportunities and threats of MOOC are beginning to emerge (e.g., Department for Business, Innovation and Skills, 2013; Jacoby, 2014; Liyanagunawardena, Adams \& Williams, 2013), the current state of thinking about MOOCs, and particularly the research landscape, in Europe remains relatively immature. That said, Jansen, Schuwer, Teixeira \& Aydin (2015) show in their recent mapping survey of current and planned European MOOC activity that the area is developing quickly. As more European initiatives are launched, millions of people around the world continue to participate in MOOCs through a small but growing diversity of courses and platforms; and they continue to attract a high level of interest from senior politicians, policy-makers and popular media. However, far less is known about what experienced educators working at the key face of higher education in Europe think about the MOOC movement.

Set against the above claims and counter-claims, the paper describes an effort to address this gap in the literature by documenting the opportunities and threats of the MOOC movement, as perceived by a purposive sample of experienced ODL leaders working in the area. In this regard, the study sought to hear from a selected group of European educators with a strong commitment to the goal of opening up access to higher education. More specifically, the study was designed to investigate the research question: What do experienced ODL educators within Europe perceive as the main opportunities and threats presented by the MOOC movement?

This work is licensed under a Creative Commons Attribution 4.0 International License. 


\section{Methodology}

This study intended to explore the current and future perceived impact of MOOCs on higher education in Europe, specifically by examining the opportunities and threats that may be presented. It sought to analyse this problem from the perspective of the ODL research tradition. To this end, it aimed to give voice to those actively engaged in ODL both as practitioners and researchers. Accordingly the research question whose answer was sought in this study was:

What do experienced ODL educators within Europe perceive as the main opportunities and threats presented by the MOOC movement?

The study was designed based on the Strengths Weaknesses Opportunities Threats (SWOT) analysis framework. The SWOT framework, used as an instrument for formulating conceptualisations and theories, has a long tradition and established applicability in a wide variety of domains (Ghazinoory, Abdi \& Azadegan-Meh, 2001; Zavadskas, Turskis \& Tamosaitiene, 2011). The research team decided to focus on only opportunities and threats, and ignore strengths and weaknesses of MOOCs as those components in the matrix that relate to external or environmental aspects and not specifically to any organisation, institution, or course. Opportunities refer to those favourable aspects that can provide an advantage of implementing MOOCs, or aspects that remain unexplored or unexploited. On the other hand, threats (which could be interpreted as weaknesses under alternative formulations) refer to all those aspects that could cause problems for the success of the MOOC movement in Europe. Both opportunities and threats lead to challenges that European policies, institutions, or courses should address.

A European conference on MOOCs was identified as the study site. This event provided the locus around which the study was anchored as it contained a range of participants from over twenty five countries in Europe, almost all of whom were active in either MOOC related research and/or the development, design, and delivery of MOOCs. The conference - titled "Mapping The European MOOC Territory" 1 - was held in Porto on 27 November 2014 as part of a European funded project known as HOME (Higher Education Online: MOOCs the European way). The HOME project aims to "develop and strengthen an open network for European cooperation on open education, in general, and MOOCs, in particular" (HOME project, 2015, para. 1). Conference attendees were drawn equally from ODL institutions and from universities with either a history of dual-mode provision or a newly acquired experience in this area. A number of invited experts from industry, national policy bodies, and other professional organisations involved in higher education were also present.

\section{Instrumentation}

The research team, comprising the work-package leaders of the HOME Project, formulated an approach through design conversations that took place at both face-to-face meetings and

\footnotetext{
${ }^{1}$ See http://home.eadtu.eu/images/News/Home_Conference_Final.pdf This work is licensed under a Creative Commons Attribution 4.0 International License.
} 
remotely using web conferencing and synchronous communication channels. A study design was iterated that took an approach that would analyse three sources of data.

The first source of data was the academic outputs of the conference itself, which comprised 15 papers from a combined total of 33 named authors. The research team examined qualitatively these papers in order to identify the opportunities and threats expressed.

The second data source comprised the views of conference attendees, as reported via a concise survey instrument which was designed to address directly and solely their views on the opportunities and threats posed by MOOCs.

The survey consisted of three open questions:

1. In your opinion what are the main opportunities of the MOOC movement for higher education in Europe?

2. In your opinion what are the main threats the MOOC movement poses for higher education in Europe?

3. (Optional) who are you?

The third data source was a selection of the tweets of conference attendees. Participants sending tweets were instructed to use the following hashtags during the conference sessions:

- \#MOOCopp to tag an opportunity

- \#MOOCthreat to tag a threat

The second and third data sources above were identified to provide context and counterpoint to the first, that of the papers. This was intended to allow the indirect object of study - the participant and presenter views - to become more context-dependant (Flyvbjerg, 2006). In effect this was to provide a form of triangulation represented by a multiplicity of evaluators, particularly the participants themselves i.e. in positioning the surveys and tweets as in effect feedback loops to the latent themes of the conference presentations.

\section{Participants}

As previously mentioned the HOME Conference was the anchoring site for data collection. For the first data source the analysed papers were Brown \& Costello, 2014; Cooch, Foster \& Costello, 2014; Cooperman, 2014; Dillenbourg, 2014; Gaisch \& Jadin, 2014; Kalz, Kreijns, Niellissen, Castaño-Muñoz, Guasch, Espasa, Floratos, Tovar, \& Cabedo, 2014; Muhlstein-Joliette, 2014; Mystakidis \& Berki, 2014; Naert, 2014; Nkuyubwatsi, 2014; Santos, Costa \& Aparicio, 2014; Siller \& Muuß-Merholz, 2014; Teixeira, Volungevičiene \& Mazar, 2014; Truyen, 2014 and Valkenburg, Kos \& Ouwehand, 2014.

This work is licensed under a Creative Commons Attribution 4.0 International License. 
The second instrument, the online survey, was open to all the Conference participants during the first two weeks of December 2014. In total 16 responses were received.

The third source of data was the tweets of the conference participants. In total, 98 tweets were posted carrying one or both tags. Some of those tweets were only informative and did not address an opportunity or a threat. These tweets were not taken into account in the analysis. For each tweet, the number of retweets and number of people tagged them as favorite was available in the data. These numbers can indicate the importance of the item being an opportunity or a threat. Table 1 presents an overview of the number of tweets per type and tag.

Table 1

Quantities of Tweets Posted

\begin{tabular}{|l|l|l|l|}
\hline & \#MOOCopp & \#MOOCthreat & Total (N=98) \\
\hline Only informative & & 15 & 15 \\
\hline Carrying an opinion & 59 & 24 & 83 \\
\hline
\end{tabular}

\section{Procedure}

In accordance with the design of the study, a SWOT analysis was adopted here along with a perspective informed by thematic analysis (Braun \& Clarke, 2006) as a flexible instrument that could be used by a large and distributed research team to analyse the three data sources in a consistent way. To differentiate emerging themes a three level thematic conceptualisation was imposed with micro, macro and meso levels (Yurdusev, 1993).

However, in exploratory analysis it became clear that the meso level would most usefully be merged into its adjacent to provide more coherence and to focus the study upon real bottom-up practitioner perspectives on the one hand, and issues that might affect entire sectors on the other. This led to a formulation where the macro level was defined as comprising those issues related to the higher education system, European context, historical period and institutional level. The micro level covered those aspects related to faculty, professors and courses, i.e. the operational level. Institutional strategic concerns (which could be meso-concerns) were included in the macro level.

At an international level, different studies and reports have identified the main topics in the agenda for MOOCs. Gil-Jaurena and Titlestad (2013) compiled issues and recommendations relating to building of foundations for MOOCs and practical suggestions for their use, primarily addressed to higher education institutions which provide open, distance, and flexible education; 
these recommendations were structured around the following strands: equity (about MOOCs and their relationship to inclusion, social justice, and social mission of open education.); diversity (about considering contextual aspects when producing/consuming MOOCs); quality (about improving MOOCs considering pedagogical and managerial related aspects) and innovation (regarding innovation and research related aspects). ICDE and UNESCO (2014) stress the following as a main political challenge in the context of Open Education: "it is not only having equal access that leads to equity, it is having equal access to success, regardless of learning difficulties, social backgrounds and other barriers" (p. 2) in order to meet the overarching education goal of the post-2015 education agenda, that is, "to ensure equitable and inclusive quality education and lifelong learning for all by 2030" (UNESCO, 2015, p. 5). The different categories identified in the literature complement the categorization we propose here (micro/macro level). At a European level, those same concerns about equity, diversity, quality and innovation are reflected.

Many sources also mentioned some of those challenges the MOOC movement offers for Europe. An example of a challenge is the construction of a European multilingual portal with common indicators, descriptors and standards, eQuality labels for MOOCs, and a common glossary (Muhlstein-Joliette, 2014). Such challenges can represent either an opportunity or a threat, and because of this categorization problem were omitted from the analysis.

Finally, the analysis of the survey revealed that a majority of opportunities and threats were not specific to Europe, but could be counted within the field of MOOCs in general. We have included these instances in our results.

\section{Results}

In this section, we will present the results of the analysis, organized in the two levels mentioned above. We firstly analyse the opportunities and threats referred to as the macro level -either political, contextual, or institutional- given the relevance that diverse authors have provided to structural and institutional strategy when implementing open education and MOOCs. The micro level and operational opportunities and threats are dealt with in the following section, as a more specific approach to relevant topics to be considered when implementing MOOCs.

\section{Results on System / Macro Level}

At this macro level we have included all those aspects that are positioned at a system or institutional level.

Opportunities on system / macro level. Table 2 provides an overview of the opportunities that were mentioned more than once across all sources. 
Table 2

Opportunities on Macro Level

\begin{tabular}{|c|c|c|c|}
\hline Opportunities & Papers Citing & $\begin{array}{l}\text { \# of } \\
\text { mentions } \\
\text { in survey }\end{array}$ & $\begin{array}{l}\text { \# of tweets } \\
\text { mentioning }\end{array}$ \\
\hline ECTS & $\begin{array}{l}\text { (Dillenbourg, } \\
\text { (Nkuyubwatsi, 2014), } \\
\text { (Santos et al., 2014), } \\
\text { (Cooperman, 2014), } \\
\text { Naert, 2014) }\end{array}$ & 1 & $\begin{array}{l}6 \text { retweets; } 2 \\
\text { added to } \\
\text { favorites }\end{array}$ \\
\hline $\begin{array}{l}\text { Increased opportunities } \\
\text { for collaboration }\end{array}$ & $\begin{array}{l}\text { (Brown \& Costello, 2014), } \\
\text { (Valkenburg et al., 2014), } \\
\text { (Naert, 2014), (Siller \& } \\
\text { Muuß-Merholz, 2014) }\end{array}$ & 4 & \\
\hline $\begin{array}{l}\text { MOOC as accelerator for } \\
\text { online learning }\end{array}$ & $\begin{array}{l}\text { (Teixeira et al., 2014), } \\
\text { (Valkenburg et al., 2014) }\end{array}$ & 4 & 1 \\
\hline $\begin{array}{l}\text { Reaching new target } \\
\text { groups supported by } \\
\text { platforms that supports } \\
\text { customization of MOOCs }\end{array}$ & (Brown \& Costello, 2014) & 11 & \\
\hline $\begin{array}{l}\text { European policies on } \\
\text { MOOC }\end{array}$ & $\begin{array}{l}\text { (Nkuyubwatsi, 2014), } \\
\text { (Muhlstein-Joliette, } \\
\text { 2014), (Truyen, 2014) }\end{array}$ & 1 & 1 \\
\hline $\begin{array}{l}\text { MOOC as a tool for } \\
\text { marketing }\end{array}$ & & 3 & \\
\hline Research about MOOCs & $\begin{array}{l}\text { (Muhlstein-Joliette, } \\
\text { 2014), (Kalz et al. 2014) }\end{array}$ & & \\
\hline $\begin{array}{l}\text { Use of open licenses } \\
\text { considered more present } \\
\text { in Europe than in US }\end{array}$ & (Valkenburg et al., 2014) & 1 & 1 \\
\hline
\end{tabular}


Across all sources (tweets, survey and the papers) the most cited opportunity is the availability of the ECTS, making possible a uniform recognition of accomplishments across Europe. On the one hand this can be viewed in light of existing European policies, aiming at collaboration across borders, thereby potentially boosting MOOC development. The "Opening up education" communication by the European Commission (EC, 2013) is an example of this. Some European countries also lead in best practices in terms of recognition of prior learning (RPL) e.g. the Norwegian RPL system constitutes a framework through which MOOC students could be assessed and awarded credit (Nkuyubwatsi, 2014). On the other hand, MOOCs may be a catalyst for strengthening European collaboration within the broader field of ODL by involving institutions that do not normally operate within this field. The analysis indicates that MOOCs potentially attract new institutions to online education.

Availability of a diversity of platforms with the ability to customize MOOCs makes addressing new target groups (e.g. lifelong learners) possible, thereby contributing to improved accessibility to higher education in Europe. Customization of MOOCs is enabled because of the availability of openly licensed learning materials in MOOCs.

Other opportunities mentioned are partly not specific for Europe (e.g. MOOCs as an accelerator for new conversations about online teaching and learning) or were mentioned less. Examples include MOOCs as a tool for marketing for institutions, improving visibility of European higher education offerings outside of Europe, pursuing strategic goals formulated in the Digital Agenda, and increasing employment, via a more specialized workforce and economic growth (Mystakidis \& Berki, 2014).

Threats on system / macro level. Table 3 provides an overview of the threats that were mentioned more than once across all sources.

Table 3

Threats on Macro Level

\begin{tabular}{|l|l|l|l|}
\hline Threats & Papers Citing & $\begin{array}{l}\text { \# Of } \\
\text { Mentions In } \\
\text { Survey }\end{array}$ & $\begin{array}{l}\text { \# Of Tweets } \\
\text { Mentioning }\end{array}$ \\
\hline $\begin{array}{l}\text { Lack of recognition } \\
\text { and accreditation }\end{array}$ & $\begin{array}{l}\text { (Nkuyubwatsi, 2014), } \\
\text { (Valkenburg et al., 2014), } \\
\text { (Muhlstein-Joliette, 2014) }\end{array}$ & 4 & 6 retweets \\
\hline Worries about quality & $\begin{array}{l}\text { (Nkuyubwatsi, 2014), } \\
\text { (Santos et al., 2014), }\end{array}$ & 4 & \\
\hline
\end{tabular}

This work is licensed under a Creative Commons Attribution 4.0 International License. 


\begin{tabular}{|c|c|c|c|}
\hline & (Muhlstein-Joliette, 2014) & & \\
\hline $\begin{array}{l}\text { Missing evidence and } \\
\text { data }\end{array}$ & $\begin{array}{l}\text { (Valkenburg et al., 2014), } \\
\text { (Kalz et al., 2014) }\end{array}$ & 1 & $\begin{array}{l}4 \text { retweets; } 2 \\
\text { added to } \\
\text { favorites }\end{array}$ \\
\hline $\begin{array}{l}\text { Too much regulation, } \\
\text { hindering innovation }\end{array}$ & $\begin{array}{l}\text { (Brown \& Costello, 2014), } \\
\text { (Teixeira et al., 2014) }\end{array}$ & 1 & 1 \\
\hline $\begin{array}{l}\text { Lack of institutional } \\
\text { strategies for } \\
\text { integrating MOOCs }\end{array}$ & $\begin{array}{l}\text { (Brown \& Costello, 2014), } \\
\text { (Teixeira et al., 2014), } \\
\text { (Truyen, 2014) }\end{array}$ & 5 & \\
\hline $\begin{array}{l}\text { Sustainability and } \\
\text { costs }\end{array}$ & $\begin{array}{l}\text { (Nkuyubwatsi, } \\
\text { (Truyen, 2014) }\end{array}$ & & \\
\hline Inequality in access & & 6 & \\
\hline
\end{tabular}

Whilst the biggest opportunity considered is the ECTS, the lack of a sound implementation of it was mentioned as a big threat for MOOCs, particularly if the issue of bridging informal and formal learning is not addressed sufficiently. In the long run, a threat to MOOCs may manifest, if they are not well-integrated in broader university strategies and do not establish their own role within the university offerings. Missing strategies on an institutional level to integrate MOOCs and connect them with mainstream activities may hinder their uptake. Too much regulation was seen as hindering innovation in MOOCs. In addition the fragility of MOOCs is addressed in several sources that highlight a lack of evidence and research data, for instance on the impact of MOOCs. This relates to a widespread scepticism of the quality of MOOCs and the pedagogies employed, for example those of xMOOCs (Gaisch \& Jadin, 2014). The costs of MOOCs production and uncertainty about sustainability in lifecycle planning are also mentioned as threats. Examples of inequality in access mentioned are: persistence in MOOCs only achievable for privileged learners (those who have previously attained higher education qualifications); publishing MOOCs is only achievable for large, well established institutions; and massiveness may disincentivize MOOCs for smaller language groups.

Poor quality MOOCs and poor pedagogies are considered a threat in several ways. The lack of quality can damage the reputation of the institution and paints a false picture to society of MOOCs as being the best of higher education has to offer. Other threats mentioned several times include: the risk of commercialisation of higher education; competition (from other institutions, in Europe or elsewhere); fragmentation in offerings in terms of approaches, technology and 
markets (Santos et al., 2014) because of the many platforms; and an excessive focus on the European situation at the risk of losing sight of the wider global view (Valkenburg et al., 2014).

\section{Results on micro level}

At this micro level we have included all mentions positioned at the operational level, which directly concern professors, faculty and courses.

Opportunities on micro level. On the micro level, the diverse types of MOOCs offered in Europe with acronyms like Spitz $\mathrm{MOOC}^{2}$, qMOOC 3 , pMOOC 4 and eMOOCs (Gaisch \& Jadin, 2014), each with a specific rationale were considered opportunities to targeting innovative ways of teaching and learning, thereby creating better possibilities for personalized and flexible learning. Although as mentioned under threats above, MOOCs are often criticised for poor quality, they have at the same time the potential to be a test-bed for innovation in education. Mention of these opportunities are in Santos et al. (2014), Teixeira et al. (2014), Cooch et al. (2014), Siller and Muuß-Merholz (2014), Mystakidis and Berki (2014), Gaisch and Jadin (2014), and in 1 tweet and 7 responses in the survey.

Threats on micro level. The high dropout rate and low completion rate is mentioned the most in the sources [Santos et al. (2014), 8 responses in the survey]. Other threats with fewer mentions include weak peer learning capabilities, the high level of previous knowledge and competencies needed to be successful in a MOOC (Santos et al., 2014) and lack of experience with online teaching and learning with many professors (Teixeira et al., 2014).

\section{Discussion}

It can be seen that the majority of opportunities and threats are on a macro level. There is no obvious explanation for this than perhaps that the context of the HOME project deals less with MOOCs effects on the micro level. Another possible explanation may be the fact institutions are still not very experienced with the phenomena of MOOC provision and its implications. In fact, most of the opportunities and threats on the micro level focus on pedagogy and learning in a more abstract way and less on more concrete effects for teachers (e.g. the opportunity to use MOOCs as a tool for professionalization of teachers). In addition the threats mentioned are in many cases not specific for the context of Europe, but are more generic threats (e.g. the high dropout rates).

Some issues pose both opportunities and threats or can be connected to each other. ECTS is mentioned both as an opportunity and a threat. Innovation as opportunity is countered by

\footnotetext{
${ }^{2}$ See http://www.slideshare.net/EADTU/03-making-the-european-academia-more-agile-pierredillenbourg

${ }^{3}$ See http://www.slideshare.net/stylianosm/participative-design-of-qmoocs-with-deep-learningand-3d-virtual-immersive-environments

${ }^{4}$ See http://www.olds.ac.uk/blog/pmoocpedagogicalpattern
}

This work is licensed under a Creative Commons Attribution 4.0 International License. 
excessive regulation as a threat. Availability of multiple platforms for adopting MOOCs is tangled with the threat of too much fragmentation.

Reflecting on opportunities and threats for European values (equity, diversity, quality and innovation), we can observe that equity is not directly addressed in the results, although indirectly the opportunity to reach new target groups could be categorized as contributing to this value. In fact, some papers mention increasing access to $\mathrm{HE}$ and lifelong learning via MOOCs. For instance, Teixeira et al. (2014) state: "It is this scalability element that assures the lowering down of costs and can assure an even more disseminated and wider access to high quality higher education provision." (p. 25) and Brown and Costello (2014) in analysing their institutional strategy also say that MOOCs provide an opportunity for "widening access to higher education through the development of a 21st Century digital campus." (p. 136).

\section{Summary and Conclusions}

This paper has described an effort to identify the opportunities and threats of the MOOC movement with a specific focus on Europe. It has reported a study which draws on a purposive sample of ODL leaders with considerable experience and knowledge of MOOCs.

For some people working in higher education, MOOCs are already seen as passé. Indeed, when the levels of publicity surrounding MOOCs is compared to the actual numbers of courses and students, then MOOCs are perhaps best understood as "imaginary" (Fairclough, 1995); a prefiguring of possible and desired realities rather than a unified and coherent domain around which clear boundaries exist (cited in Selwyn et al., 2015).

The results of this research indicate that this is too bold a statement. The results may help to decide on future directions institutions of higher education can take to make optimal use of MOOCs, and at the same time avoiding the threats as much as possible.

The Porto Declaration on European MOOCs (EADTU, 2014), formulated during and after the previous mentioned conference, support the findings of this research. The Declaration calls for openness for all, a collective European response to MOOCs and a strengthening of collaboration between universities across Europe to that end. These are all recognized in the results of our research and can be considered as points of attention and guidance for future developments. To support such developments, the Declaration also points to the strong support of the European Commission and governments required. The latter is a prerequisite to succeed in successfully embracing the MOOC movement in Europe.

\section{Acknowledgements}

This research was conducted in the framework of the European Union-funded project HOME Higher education Online: MOOCs the European way (Ref. 543516-LLP-1-2013-1-NL-KA3KA3NW) under the support of the European Commission, DG EAC, under the Lifelong Learning

This work is licensed under a Creative Commons Attribution 4.0 International License. 
Programme. The authors wish also to extend their acknowledgements to all the contributors and participants to the conference "Mapping the European MOOC Territory" held in Porto on 27th November, 2014, for their contribution to this study.

\section{References}

Barber, M., Donnelly, K., \& Rizvi, S. (2013). An avalanche is coming: Higher education and the revolution ahead. Institute for Public Policy Research. London.

Barlow, A. (2014). Just another colonist tool? In S. Krause \& C. Lowe (Eds.), Invasion of the MOOCs: The promise and perils of massive open online courses (pp. 73-85). San Francisco: Parlor Press.

Brown, M. (2015, June 9th). Opportunities and threats of the MOOC movement for Higher Education: A European perspective. Presentation at How Europe Seizes the Opportunities Offered by MOOCs, HOME Pre-Conference Workshop, European Distance and e-Learning Network (EDEN) Conference, Barcelona.

Brown, M., \& Costello, E. (2014). MOOCs in question: Strategic insights from two institutional experiences. In D. Jansen \& A. Teixeira (eds). Position papers for European cooperation on MOOCs (pp. 130-148). Heerlen: EADTU. Retrieved from http://home.eadtu.eu/images/Position papers for European cooperation on MOOC s.pdf

Braun, V., \& Clarke, V. (2006). Using thematic analysis in psychology. Qualitative Research in Psychology, 3(2), 77-101. http://dx.doi.org/10.1191/1478088706qpo630a

Cooch, M., Foster, H. \& Costello, E. (2014). Our MOOC with Moodle. In D. Jansen \& A. Teixeira (eds). Position papers for European cooperation on MOOCs (pp. 75-98). Heerlen:

EADTU. Retrieved from http://home.eadtu.eu/images/Position papers for European cooperation on MOOC $\underline{\text { s.pdf }}$

Cooperman, L. (2014). MOOCs in the era of higher education's digital transition. In D. Jansen \& A. Teixeira (eds). Position papers for European cooperation on MOOCs (pp. 6-8). Heerlen: EADTU. Retrieved from 
http://home.eadtu.eu/images/Position papers for European cooperation on MOOC s.pdf

Daniel, J. (2012). Making sense of MOOCs: Musings in a maze of myth, paradox and possibility. Journal of Interactive Media in Education, 18(3). http://dx.doi.org/10.5334/2012-18

Department for Business, Innovation and Skills (2013). The maturing of the MOOC: Literature review of massive open online courses and other forms of online distance learning. BIS Research Paper Number 130.

Dillenbourg, P. (2014). Making european education more agile. In D. Jansen \& A. Teixeira (eds). Position papers for European cooperation on MOOCs (pp. 9-10). Heerlen: EADTU. Retrieved from http://home.eadtu.eu/images/Position papers for European cooperation on MOOC s.pdf

EADTU (2014). Porto declaration on European MOOCs. Heerlen: EADTU. Retrieved from http://home.eadtu.eu/images/News/Porto Declaration on European MOOCs Final.p $\underline{\mathrm{df}}$

EC-European Commission (2013). Opening up Education: Innovative teaching and learning for all through new Technologies and Open Educational Resources. Retrieved from http://eur-lex.europa.eu/legalcontent/EN/TXT/PDF/?uri=CELEX:52013DC0654\&from=EN

ECTS (2009). ECTS users' guide. Luxembourg: European Communities.

Flyvbjerg, B. (2006). Five misunderstandings about case-study research. Qualitative Inquiry, 12(2) 219-245. http://dx.doi.org/10.1177/1077800405284363

Gaisch, M., \& Jadin, T. (2014). Enhanced MOOCs for the conceptual age: A diversified lens on the MOOCversity. In D. Jansen \& A. Teixeira (eds). Position papers for European cooperation on MOOCs (pp. 120-129). Heerlen: EADTU. Retrieved from http://home.eadtu.eu/images/Position_papers_for_European_cooperation_on_MOOC s.pdf

Ghazinoory, S., Abdi, M. \& Azadegan-Mehr, M. (2011). SWOT methodology: A state-of-the-art review for the past, a framework for the future. Journal of Business Economics and Management, 12(1), 24-48.

Gil-Jaurena, I. (2014, November 29th). Implementation of MOOCs in a distance education university: Issues and lessons learned. Keynote speech at ICET - International 
Conference of Educational Technology. Innovative Learning Environments for Authentic Education, Seoul (South Korea).

Gil-Jaurena, I., \& Titlestad, G. (2013). ICDE: "Mind to MOOCs"-draft issues and recommendations. Retrieved from http://www.icde.org/filestore/News/2013 JulyDec/SCOP 2013/ICDEMindtoMOOCsdraftissuesandrecommendationsver1120131125.pdf

Gouseti, A. (2010). Web 2.0 and education: Not just another case of hype, hope and disappointment? Learning, Media and Technology, 35(3), 351-356. http://dx.doi.org/10.1080/17439884.2010.509353

HOME project (2013). Objectives. Retrieved from http://home.eadtu.eu/objectives

ICDE \& UNESCO. (2014, November 20th). Policy forum. ensure equitable quality education and lifelong learning for all by 2030: The contribution of open, online and flexible higher education to the post-2015 global education agenda. Bali, Indonesia. Retrieved from http://icde.org/en/context/unesco/icde - unesco policy forum/

Jacoby, J. (2014). The disruptive potential of the Massive Open Online Course: A literature review. Journal of Open, Flexible and Distance Learning, 18(1), 73-85. Retrieved from http://journals.akoaotearoa.ac.nz/index.php/JOFDL/article/view/214/168

Jansen, D., Schuwer, R., Teixeira, A., \& Aydin, H. (2015). Comparing MOOC adoption strategies in Europe: Results from the HOME project survey. International Review of Research in Open and Distributed Learning, Special Issue on European MOOCs.

Kalz, M., Kreijns, K., Niellissen, G., Castaño-Muñoz, J., Guasch, T., Espasa, A., Floratos, N., Tovar, E. \& Cabedo, R. (2014). MOOCKnowledge: Establishing a large-scale data collection about participants of European Open Online Courses. In D. Jansen \& A. Teixeira (eds). Position papers for European cooperation on MOOCs (pp. 113-119). Heerlen: EADTU. Retrieved from http://home.eadtu.eu/images/Position papers for European cooperation on MOOC s.pdf

Krause, S., \& Lowe, C. (2014). Invasion of the MOOCs: The promise and perils of massive open online courses. San Francisco: Parlor Press.

Liyanagunawardena, T. R., Adams, A. A. \& Williams, S. A. (2013). MOOCs: A systematic study of the published literature 2008-2012. International Review of Research in Open \& Distributed Learning, 14(3), 202-227. Retrieved from http://www.irrodl.org/index.php/irrodl/article/view/1455/2531 
Macleod, H., Haywood, J., Woodgate, A. \& Alkhatnai, M. (2015). Emerging patterns in MOOCs: Learners, course design and directions. TechTrends, 59(1), 56-63. http://dx.doi.org/10.1007/s11528-014-0821-y

Muhlstein-Joliette, C. (2014). eCompetences and eQuality: From MOOCs to social MOOCs in Europe. In D. Jansen \& A. Teixeira (eds). Position papers for European cooperation on MOOCs (pp. 30-32). Heerlen: EADTU. Retrieved from http://home.eadtu.eu/images/Position papers for European cooperation on MOOC s.pdf

Mystakidis, S., \& Berki, E. (2014). Towards a crowd-sourced open education strategy for employment in europe with qualification-focused MOOCs. In D. Jansen \& A. Teixeira (eds). Position papers for European cooperation on MOOCs (pp. 33-43). Heerlen: EADTU. Retrieved from http://home.eadtu.eu/images/Position_papers_for_European_cooperation_on_MOOC s.pdf

Naert, F. (2014). MOOCs, SPOCs, DOCCs and other bugs. In In D. Jansen \& A. Teixeira (eds). Position papers for European cooperation on MOOCs (pp. 64-74). Heerlen: EADTU. Retrieved from http://home.eadtu.eu/images/Position_papers_for_European cooperation on_MOOC s.pdf

Nkuyubwatsi, B. (2014). Fostering collaborative investment in Massive Open Online Courses (MOOCs). In D. Jansen \& A. Teixeira (eds). Position papers for European cooperation on MOOCs (pp. 44-57). Heerlen: EADTU. Retrieved from http://home.eadtu.eu/images/Position_papers_for_European_cooperation_on_MOOC s.pdf

OpenupEd (2015). Definition Massive Open Online Courses. Heerlen: EADTU. Retrieved from http://www.openuped.eu/images/docs/Definition_Massive_Open_Online_Courses.pdf

Santos, T., Costa, C. \& Aparicio, M. (2014). Do we need a shared European MOOC platform. In D. Jansen \& A. Teixeira (eds). Position papers for European cooperation on MOOCs (pp. 99-112). Heerlen: EADTU. Retrieved from http://home.eadtu.eu/images/Position_papers for_European cooperation on_MOOC s.pdf

Selwyn, N. (2014). Digital technology and the contemporary university: Degrees of digitalisation. London: Routledge. 
Selwyn, N., Bulfin, S. \& Pangrazio, L. (2015). Massive open online change? Exploring the discursive construction of the 'MOOC' in newspapers. Higher Education Quarterly, 69(2), 175-192. http://dx.doi.org/10.1111/hequ.12061

Siller, F., \& Muuß-Merholz, J. (2014). MOOC didactics Matters. A hands-on vision for MOOCs and Connected Learning Practices in Europe. In D. Jansen \& A. Teixeira (eds). Position papers for European cooperation on MOOCs (pp. 58-63). Heerlen: EADTU. Retrieved from http://home.eadtu.eu/images/Position papers for European cooperation on MOOC s.pdf

Teixeira, A., \& Mota, J. (2014). The iMOOC pedagogical model: Bridging the gap between nonformal and formal education. Actas del V Congreso Internacional sobre Calidad $y$ Accesibilidad de la Formación Virtual - CAFVIR 2014 (pp. 512-517). Antigua Guatemala: Galileo.

Teixeira, A., Volungevičiene; A. \& Mazar, I. (2014). The mainstreaming of open, online and flexible learning: How will MOOCs continue to be unique from an institutional perspective. In D. Jansen \& A. Teixeira (eds). Position papers for European cooperation on MOOCs (pp. 25-29). Heerlen: EADTU. Retrieved from http://home.eadtu.eu/images/Position_papers_for_European cooperation on_MOOC s.pdf

Truyen, F. (2014). MOOCs from a university resource management perspective. In D. Jansen \& A. Teixeira (eds). Position papers for European cooperation on MOOCs (pp. 11-18). Heerlen: EADTU. Retrieved from http://home.eadtu.eu/images/Position_papers_for_European_cooperation_on_MOOC s.pdf

UNESCO. (2015). Position Paper on Education Post-2015. Retrieved from http://en.unesco.org/post2015/sites/post2015/files/UNESCO Position Paper ED 2015.pdf

Valkenburg, W. van; Kos, T. \& Ouwehand, M. (2014). MOOCs as accelerator of change. In D. Jansen \& A. Teixeira (eds). Position papers for European cooperation on MOOCs (pp. 19-24). Heerlen: EADTU. Retrieved from http://home.eadtu.eu/images/Position papers for European cooperation on MOOC s.pdf

Yurdusev, A. N. (1993). 'Level of analysis' and 'unit of analysis': A case for distinction. Millennium-Journal of International Studies, 22(1), 77-88. 
Zavadskas, E. K., Turskis, Z. \& Tamosaitiene, J. (2011). Selection of construction enterprises management strategy based on the SWOT and multi-criteria analysis. Archives of Civil and Mechanical Engineering, 11(4), 1063-1082. http://dx.doi.org/10.1016/S16449665(12)60096-X

Athabasca

University

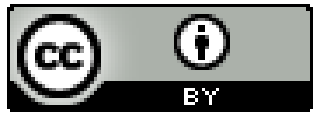

